\title{
Article
}

\section{Inner Ear Malformations in Congenital Deafness Are Not Associated with Increased Risk of Breech Presentation}

Sekulic, Slobodan, Komazec, Slobodanka, Sokolovac, Ivana, Topalidou, Anastasia, Gouni, Olga, Petkovic, Branka, Martac, Ljiljana, Kekovic, Goran, Redzek-Mudrinic, Tatjana and Capo, Ivan

Available at http://clok.uclan.ac.uk/32625/

Sekulic, Slobodan, Komazec, Slobodanka, Sokolovac, Ivana, Topalidou, Anastasia ORCID: 0000-0003-0280-6801, Gouni, Olga, Petkovic, Branka, Martac, Ljiljana, Kekovic, Goran, Redzek-Mudrinic, Tatjana et al (2020) Inner Ear Malformations in Congenital Deafness Are Not Associated with Increased Risk of Breech Presentation. Fetal and Pediatric Pathology . pp. 1-11. ISSN 1551-3815

It is advisable to refer to the publisher's version if you intend to cite from the work. http://dx.doi.org/10.1080/15513815.2020.1737993

For more information about UCLan's research in this area go to http://www.uclan.ac.uk/researchgroups/ and search for <name of research Group>.

For information about Research generally at UCLan please go to http://www.uclan.ac.uk/research/

All outputs in CLoK are protected by Intellectual Property Rights law, including Copyright law. Copyright, IPR and Moral Rights for the works on this site are retained by the individual authors and/or other copyright owners. Terms and conditions for use of this material are defined in the policies page. 


\title{
Inner Ear Malformations in Congenital Deafness Are Not Associated with Increased Risk of Breech Presentation
}

\author{
Slobodan Sekulic ${ }^{\mathrm{a}}$, Slobodanka Komazec ${ }^{\mathrm{b}}$, Ivana Sokolovac ${ }^{\mathrm{b}}$, Anastasia Topalidou ${ }^{\mathrm{c}}$, \\ Olga Gouni ${ }^{d}$, Branka Petkovic ${ }^{\mathrm{e}}$, Ljiljana Martac ${ }^{\mathrm{e}}$, Goran Kekovic ${ }^{f}$, Tatjana Redzek- \\ Mudrinic $^{g}$, and Ivan Capo ${ }^{\text {h }}$ \\ ${ }^{a}$ Department of Neurology, Faculty of Medicine Novi Sad, University of Novi Sad, Novi Sad, Serbia; \\ ${ }^{b}$ Department of Otorhinolaryngology, Faculty of Medicine Novi Sad, University of Novi Sad, Novi Sad, \\ Serbia; 'School of Community Health and Midwifery, Faculty of Health and Wellbeing, University of \\ Central Lancashire, Research in Childbirth and Health Unit, Preston, United Kingdom of Great Britain \\ and Northern Ireland; ${ }^{d}$ National and Kapodistrian University of Athens, Athens, Greece; ${ }^{e}$ Department of \\ Neurophysiology, Institute for Biological Research Sinisa Stankovic, Belgrade, Serbia; ${ }^{\text {fDepartment of }}$ \\ Electrical and Computer Engineering, Faculty of Maritime, Academic study, Belgrade, Serbia; \\ ${ }^{9}$ Department of Neuropediatrics, Child and Youth Health Care Institute of Vojvodina, Faculty of \\ Medicine Novi Sad, University of Novi Sad, Novi Sad, Serbia; ${ }^{\text {h}}$ Faculty of Medicine NoviSad, University of \\ Novi Sad, Novi Sad, Serbia
}

\begin{abstract}
Background: There is speculation that an immature vestibular system may be associated with breech presentation at delivery. Our aim was to determine whether syndromes with congenital inner ear malformations were accompanied by a higher frequency of breech presentation/malpresentations than in the general population ( $2 \%-3 \%)$. Methods: A review was conducted for published literature using PubMed/MEDLINE (1936-2016), to determine frequency of breech presentation and transverse lie in cases with congenital deafness (Michel aplasia, Wildervanck syndrome, Mondini-Alexander dysplasia, Waardenburg syndrome, CHARGE syndrome, Large vestibular aqueductal syndrome, Pendred syndrome, Oculo-aurico-vertebral spectrum, Jervel and Lange-Nielsen syndrome, Usher syndrome, and Scheibe dysplasia) and vestibular nerve aplasia. Results: Identified were total of 122 cases. The frequency of breech presentation was $1.64 \%$, and of transverse lie $1.64 \%$, giving a total of $3.28 \%$ malpresentations. Conclusion: The results of the study suggest that congenital malformations of the vestibular apparatus are not associated with the increased risk of breech presentation at delivery.
\end{abstract}

\section{ARTICLE HISTORY}

Received 21 January 2020 Revised 6 February 2020 Accepted 11 February 2020

\section{KEYWORDS}

congenital deafness; inner ear malformation; breech presentation; vestibular malformation; fetus; gestation

\section{Introduction}

The fetus changes its presentation by active whole-body movements, such as kicking [1]. Fetal kicking represents a sudden extension of the trunk and lower limbs, as a result of excitations of the extensor muscles. Vestibular nuclei, which are under constant afferent activity of the vestibular apparatus, excite extensor muscles of the trunk and lower extremities [2]. The vestibular labyrinth acquires adult morphology and size during the 
$5^{\text {th }}$ gestational month [3]. The myelinization of the vestibular nerve begins in the $17^{\text {th }}$ gestational week and ends prenatally [4].

Congenital deafness is accompanied by abnormalities in the function of the vestibular apparatus in $80 \%-85 \%$ of the cases $[5,6]$. Pathological substrates of the congenital deafness are complex malformations of the cochlea and vestibular apparatus.

The purpose of this study was to perform a literature review to determine whether syndromes with congenital inner ear malformations are accompanied by a higher frequency of breech presentation/malpresentations than in the general population, where the frequency is $2 \%-3 \%$ [7].

\section{Material and methods}

The literature search was conducted in PubMed/MEDLINE by two authors (November 2016). The selected key words related to the inner ear malformations and syndromes, according to Omerod's classification [8] were "Michel aplasia", "Wildervanck syndrome", "Mondini-Alexander dysplasia", "Waardenburg syndrome", "CHARGE syndrome", "Large vestibular aqueductal syndrome", "Pendred syndrome", "Oculo-aurico-vertebral spectrum", "Jervel and Lange-Nielsen syndrome", "Usher syndrome" and "Scheibe dysplasia". Considering that vestibulocochlear nerve aplasia leads to a complete deafferentation from the vestibular apparatus, we included this medical entity in the search with key words: "aplasia", "vestibulocochlear nerve" and "vestibular nerve".

We included only publications that described case reports or series (in humans) and provided information of fetal presentation in single-fetus pregnancies (singleton). In addition to the term "cephalic presentation", the terms "uneventful birth", "unremarkable birth history", "normal vaginal delivery", "uncomplicated delivery", "normal delivery", "uneventful perinatal" and "uneventful intranatal period", were considered as cephalic presentation. Duplicate articles were automatically identified by the search tool and removed from the database prior to screening. Two authors reviewed the findings to reduce the risk of selection bias. First, the two reviewers screened the publications by title and abstract. Publications which fulfilled the inclusion criteria were screened in full text.

\section{Results}

Research covered the period from 1936 to 2016. The literature search resulted in $\mathrm{n}=5837$ citations (after de-duplication). In the first stage $\mathrm{n}=5579$ articles were excluded by review of title and abstract. At the second stage, 258 articles met the eligibility criteria based on title/abstract and the corresponding full-text articles were procured for review. Finally, $\mathrm{n}=91$ records were included in the study. The included records described 122 births that were analyzed and described in the current study.

Malformation according to reference numbers were Michel aplasia [9-11], Wildervanck syndrome [12-26], Mondini-Alexander dysplasia [9, 17-25], Waardenburg syndrome type I [26-36], Waardenburg syndrome type II [37-41], Waardenburg syndrome type III [42-46], Waardenburg syndrome type IV [47-54], CHARGE syndrome [55-63], Large vestibular aqueductal syndrome [64-71], Pendred syndrome [72-77], 
Table 1. Presentation and lie at delivery in cases of vestibulocochlear dysplasias with associated disorders.

\begin{tabular}{|c|c|c|c|c|}
\hline Description of malformations & $\begin{array}{l}\text { Malformations and } \\
\text { associated syndroms }\end{array}$ & $\mathrm{CP} n=$ & $\mathrm{BP} n=$ & $\mathrm{TL} n=$ \\
\hline \multirow{2}{*}{$\begin{array}{l}\text { Complete lack of inner ear } \\
\text { development }\end{array}$} & Michel aplasia & 3 & 0 & 0 \\
\hline & Wildervanck syndrome & 5 & 0 & 0 \\
\hline \multirow{6}{*}{$\begin{array}{l}\text { Cochlea contains a decreased } \\
\text { number of turns and } \\
\text { underdevelopment of } \\
\text { vestibular structures }\end{array}$} & Mondini-Alexander dysplasia & 12 & 0 & 0 \\
\hline & Waardenburg syndrome Type I & 13 & 0 & 0 \\
\hline & Waardenburg syndrome Type II & 5 & 0 & 0 \\
\hline & Waardenburg syndrome Type III & 6 & 0 & 0 \\
\hline & Waardenburg syndrome Type IV & 8 & 0 & 0 \\
\hline & CHARGE syndome & 17 & 0 & 2 \\
\hline \multirow[t]{2}{*}{$\begin{array}{l}\text { Large vestibular } \\
\text { aqueductal syndrome }\end{array}$} & $\begin{array}{l}\text { Large vestibular } \\
\quad \text { aqueductal syndrome }\end{array}$ & 11 & 1 & 0 \\
\hline & Pendred syndrome & 6 & 0 & 0 \\
\hline \multirow{3}{*}{$\begin{array}{l}\text { membranous labyrinth. Normal } \\
\text { bony labyrinth }\end{array}$} & Oculo-auriculo-vertebral spectrum & 10 & 0 & 0 \\
\hline & $\begin{array}{l}\text { Jervel and Lange- } \\
\text { Nielsen syndrome }\end{array}$ & 13 & 0 & 0 \\
\hline & Usher syndrome Type I & 4 & 0 & 0 \\
\hline $\begin{array}{l}\text { Malformation of the } \\
\text { membranous cochlea } \\
\text { and saccule }\end{array}$ & Scheibe dysplasia & 1 & 0 & 0 \\
\hline Aplasia of the vestibular nerve & Pontine tegmental cap dysplasia & 4 & 1 & 0 \\
\hline Total cases & & 118 & 2 & 2 \\
\hline
\end{tabular}

$\mathrm{CP}-$ Cephalic Presentation, BP - Breech Presentation, $\mathrm{TL}-$ Transverse Lie, $\mathrm{n}=-$ number of cases.

Oculo-aurico-vertebral spectrum [78-85], Jervel and Lange-Nielsen syndrome [86-90], Usher syndrome [91-94], Scheibe dysplasia [95], and Pontine tegmental cap dysplasia [96-99].

The frequency of breech presentation was $1.64 \%$ and of transverse lie $1.64 \%$, giving a total of $3.28 \%$ (Table 1).

Table 2 presents cases derived from the first table in which malformations of the vestibular apparatus were described (utriculus, sacculus, semicircular canals) based on radiological examinations (Computed Tomography or Magnetic Resonance Imaging). Breech presentation and transverse lie was not reported in any of these cases.

Only in five cases, one with Wildervanck [16] and four with Mondini-Alexander dysplasia [25], was data provided about the vestibular function. In all five cases presentations were cephalic and caloric examination revealed total absence of vestibular response bilaterally $[16,25]$. Damped rotation test elicited per-rotatory nystagmus in the four examined children with Mondini-Alexander dysplasia but the duration and total number of nystagmic beats were decreased compared with healthy children of the same age $[16,25]$.

\section{Discussion}

This paper is the first to provide a comprehensive overview of existing studies on inner ear malformation in congenital deafness and its association with breech presentation. The obtained frequency of breech presentation in congenital deafness was $1.64 \%$, while in the general population it is $2 \%-3 \%$ [7].

Prior to the current study, only one other study published data related to congenital deafness and malpresentations [100]. This article did not analyze specific syndromes of 
S. SEKULIC ET AL.

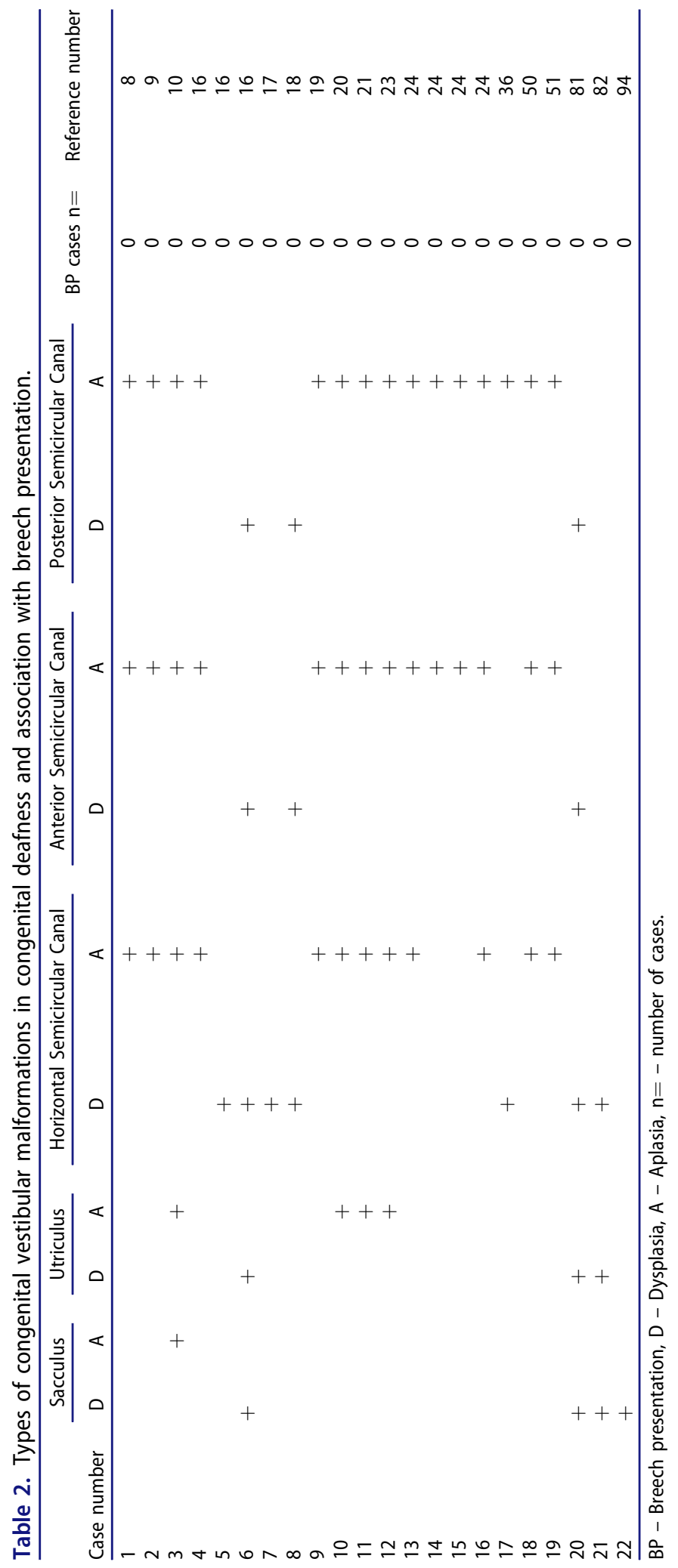


congenital deafness. The obtained frequency of breech presentation in this study does not differ from the data reported in the present study. The results from both studies indicate that the abnormal function of the vestibular apparatus was not associated with an increased risk of breech presentation.

In the examined types of congenital deafness there were a high proportion of cases with abnormal function of the vestibular apparatus. In four out of ten patients with Waardenburg syndrome and hearing impairment, the torsion swing test showed a directional preponderance of nystagmus. The caloric test was abnormal in five out of ten patients [101]. The frequency of abnormal function of the vestibular apparatus in CHARGE syndrome was 100\%; however, a residual response could be registered in $94 \%$ $[102,103]$. Large vestibular aqueductal syndrome was also often accompanied by abnormal vestibular function. In another study investigating the association between Jervell and Lange-Nielsen Syndrome (JLNS) genotype and vestibular dysfunction, an abnormal post-rotatory finding was seen in 9/9 examined cases, while 3 of them had a complete lack of vestibular function [104]. In 16 examined patients with Usher syndrome Type I there was no nystagmic response on the caloric test, while the results of the rotatory test were abnormal in 11 patients [105].

However, given the presence of the residual function of the vestibular apparatus in cases of congenital inner ear malformation, it is possible that the residual function of the vestibular apparatus is sufficient for occupying cephalic presentation in the second half of gestation.

Beside the vestibular apparatus, vestibular nuclei receive input from proprioceptive, visual, tactile, and auditory sources. Based on all these sensory inputs, the vestibular system generates efferent motor activity [2]. Characteristic of the vestibular nuclei is spontaneous discharges even in the absence of afferentation by the vestibular apparatus [106]. The plasticity of the central nervous system provides the possibility of compensation after the vestibular apparatus has lost its function [2]. The above suggests that even when the vestibular apparatus is absent, the function of the vestibular system can assumed by other means.

The results of our study showed that congenital malformations of the vestibular apparatus and its abnormal function do not increase the risk of breech presentation. The residual function of the vestibular apparatus could be sufficient for fetus to occupy cephalic presentation. When the function of the vestibular apparatus is absent, the vestibular system can still take part in regulation of fetal presentation, because of sensory afferentation from proprioceptive and cutaneous system.

\section{Disclosure statement}

No potential conflict of interest was reported by the author(s).

\section{Funding}

This study was supported by the COST Action CA 18211 Perinatal Mental Health and BirthRelated Trauma: Maximizing best practice and optimal outcomes as well as by the Serbian Ministry of Education, Science and Environmental Protection, grant No. 175006. 


\section{References}

[1] Suzuki S, Yamamuro T. Fetal movement and fetal presentation. Early Hum Dev. 1985; 11(3-4):255-63. doi:10.1016/0378-3782(85)90079-9.

[2] Hain TC, Helminski J. Anatomy and physiology of the normal vestibular system. In: Herdman SJ, Clendaniel RAFA, editors. Vestibular rehabilitation. Phyladelphia (PA): Davis Company; 2014. p. 2-18.

[3] Elliott GB, Elliott KA. Some pathological, radiological and clinical implications of the precocious development of the human ear. Laryngoscope. 1964;74:1160-71. doi:10.1288/ 00005537-196408000-00009.

[4] Yakovlev PL, Lecours AR. The myelogenetic cycles of regional maturation of the brain. In: Minkowski A, editor. Regional development of the brain in early life. Oxford (UK): Blackwell; 1967. pp. 3-70.

[5] Kaga K, Shinjo Y, Jin Y, Takegoshi H. Vestibular failure in children with congenital deafness. Int J Audiol. 2008;47(9):590-9. doi:10.1080/14992020802331222.

[6] Lin BY, Young YH. Assessing residual vestibular function in adults with congenital hearing loss. Eur Arch Otorhinolaryngol. 2016;273(12):4209-14. doi:10.1007/s00405-0164137-8.

[7] Sekulić SR, Mikov A, Petrović DS. Probability of breech presentation and its significance. J Matern Fetal Neonatal Med. 2010;23(10):1160-4. doi:10.3109/14767051003677996.

[8] Scott DA, Carey JC. Vestibulocochlear dysplasias. Inner ear. In: Stevenson RE, Hall JG, editors. Human malformations and related anomalies. New York (NY): Oxford University Press Inc; 2006. p. 366-9.

[9] Ben-Shoshan M, DeRowe A, Grisaru-Soen G, Ben-Sira L, Miller E. Recurrent meningitis and cerebrospinal fluid leak-two sides of the same vestibulocochlear defect: report of three cases. Eur J Pediatr. 2007;166(3):269-72. doi:10.1007/s00431-006-0236-7.

[10] Hersh JH, Ganzel TM, Fellows RA. Michel's anomaly, type I microtia and microdontia. Ear Nose Throat J. 1991;70(3):155-7.

[11] Santos PF, Neto SC, Neto SR, Caldas N, Junior AP. Aplasia de Michel: relato de caso e revisao de literatura. Braz J Otorhinolaryngol. 2001;67(4):569-72.

[12] Cremers CW, Hoogland GA, Kuypers W. Hearing loss in the cervico-oculo-acoustic (Wildervanck) syndrome. Arch Otolaryngol. 1984;110(1):54-7. doi:10.1001/archotol.1984. 00800270058015.

[13] Dirik E, Yiş U, Dirik MA, Cakmakçi H, Men S. Vertebral artery dissection in a patient with Wildervanck syndrome. Pediatr Neurol. 2008;39(3):218-20. doi:10.1016/j.pediatrneurol.2008.06.005.

[14] Kumar A, Sahu A, Shetty S, Vijayalakshmi P. Wildervanck syndrome associated with cleft palate and short stature. Indian J Ophthalmol. 2010;58(4):323-5. doi:10.4103/03014738.64120 .

[15] Meshram SS, Nikose S, Jain S, Taksande A. Wildervanck syndrome with hypoplastic frontal sinus: A rare case presentation. Indian J Hum Genet. 2014;20(2):189-91. doi:10. 4103/0971-6866.142899.

[16] Regenbogen L, Godel V. Cervico-oculo-acoustic syndrome. Ophthalmic Paediatr Genet. 1985;6(3):183-7. doi:10.3109/13816818509087639.

[17] Bodensteiner JB, Smith SD, Schaefer GB. Hypotonia, congenital hearing loss, and hypoactive labyrinths. J Child Neurol. 2003;18(3):171-3. doi:10.1177/08830738030180030701.

[18] Elverland HH, Mair IW. Recurrent meningitis, congenital anacusis and Mondini anomaly. Acta Otolaryngol. 1983;95(1-4):147-51. doi:10.3109/00016488309130928.

[19] Fitch N, Lindsay JR, Srolovitz H. The temporal bone in the preauricular pit, cervical fistula, hearing loss syndrome. Ann Otol Rhinol Laryngol. 1976;85(2):268-75. doi:10.1177/ 000348947608500212.

[20] Monsell EM, Jackler RK, Motta G, Linthicum FH. Congenital malformations of the inner ear: histologic findings in five temporal bones. Laryngoscope. 2009;97(S40):18-24. doi:10. 1002/lary.5540971303. 
[21] Paparella MM, ElFiky FM. Mondini's deafness. Arch Otolaryngol. 1972;95(2):134-40. doi:10.1001/archotol.1972.00770080222009.

[22] Paparella MM. Mondini's deafness. A review of histopathology. Ann Otol Rhinol Laryngol. 1980;89(2 Pt 3):1-10. doi:10.1177/00034894800892s301.

[23] Qadeer S, Junaid M, Sobani ZA, Nadeem N, Awans MS. Cochlear implant in a patient with Mondini's deformity of the cochlea: pilot patient in Pakistan. J Pak Med Assoc. 2013;63(7):913-5.

[24] Sekhar HK, Sachs M. Mondini defect in association with multiple congenital anomalies. Laryngoscope. 1976;86(1):117-25. doi:10.1288/00005537-197601000-00023.

[25] Tsuzuku T, Kaga K. Delayed motor function and results of vestibular function tests in children with inner ear anomalies. Int J Pediatr Otorhinolaryngol. 1992;23(3):261-8. doi: 10.1016/0165-5876(92)90108-2.

[26] Amin-Zaki L. An Arab family with Waardenburg syndrome. J Laryngol Otol. 1971;85(5): 471-80. doi:10.1017/S0022215100073692.

[27] Bansal Y, Jain P, Goyal G, Singh M, Mishra C. Waardenburg syndrome-a case report. Cont Lens Anterior Eye. 2013;36(1):49-51. doi:10.1016/j.clae.2012.10.083.

[28] Demirci GT, Atıs G, Altunay IK. Waardenburg Syndrome type 1: A case report. Dermatol Online J. 2011;17((11):3.

[29] Al Gazali LI, Quaife R. Two sibs with unbalanced translocations in the Waardenburg gene region. J Med Genet. 1993;30(7):607-9. doi:10.1136/jmg.30.7.607.

[30] Ishikiriyama S, Tonoki H, Shibuya $Y$, Chin S, Harada N, Abe K, Niikawa N. Waardenburg syndrome type I in a child with de novo inversion (2)(q35q37.3). Am J Med Genet. 1989;33(4):505-7. doi:10.1002/ajmg.1320330419.

[31] Jutras B, Russell LJ, Hurteau AM, Chapdelaine M. Auditory neuropathy in siblings with Waardenburg's syndrome. Int J Pediatr Otorhinolaryngol. 2003;67(10):1133-42. doi:10. 1016/S0165-5876(03)00200-3.

[32] Morgaonkar M, Gupta S, Vyas K, Jain SK. Multiple hyperpigmented patches in Waardenburg syndrome type 1: An unusual presentation. Indian J Dermatol Venereol Leprol. 2016;82(6):711-13. doi:10.4103/0378-6323.188657.

[33] Nutman J, Nissenkorn I, Varsano I, Mimouni M, Goodman RM. Anal atresia and the Klein-Waardenburg syndrome. J Med Genet. 1981;18(3):239-41. doi:10.1136/jmg.18.3. 239.

[34] Ptok M, Morlot S. Unilateral sensineural deafness associated with mutations in the PAX3-gene in Waardenburg syndrome type I. HNO. 2006;54(7):557-60. doi:10.1007/ s00106-005-1315-1.

[35] Thapa R, Mallick D, Ghosh A, Ghosh A. Waardenburg syndrome associated with laryngomalacia. Singapore Med J. 2009;50(12):401-3.

[36] Yoshino M, Nakao M, Shiotsuki Y, Nishiyori A, Yamashita F, Karukaya S, Yoshimura H, Nishida H, Shiotani N, Sugita A. Incidences of dystopia canthorum and some other signs in a family with Waardenburg syndrome type I. Jap J Human Genet. 1986;31(4):373-8. doi:10.1007/BF01907938.

[37] Chen K, Zong L, Liu M, Zhan Y, Wu X, Zou W, Jiang H. De novo dominant mutation of SOX10 gene in a Chinese family with Waardenburg syndrome type II. Int J Pediatr Otorhinolaryngol. 2014;78(6):926-9. doi:10.1016/j.ijporl.2014.03.014.

[38] Jacobs JM, Wilson J. An unusual demyelinating neuropathy in a patient with Waardenburg's syndrome. Acta Neuropathol. 1992;83(6):670-4. doi:10.1007/BF00299420.

[39] Kawabata E, Ohba N, Nakamura A, Izumo S, Osame M. Waardenburg syndrome: a variant with neurological involvement. Ophthalmic Paediatr Genet. 1987;8(3):165-70. doi:10. 3109/13816818709031463.

[40] Wenzhi H, Ruijin W, Jieliang L, Xiaoyan M, Haibo L, Xiaoman W, Jiajia X, Shaoying L, Shuanglin L, Qing L. Heterozygous deletion at the SOX10 gene locus in two patients from a Chinese family with Waardenburg syndrome type II. Int J Pediatr Otorhinolaryngol. 2015;79(10):1718-21. doi:10.1016/j.ijporl.2015.07.034. 
[41] Wong J. A male infant who has a white hair tuft and hypopigmented macules. Pediatr Rev. 2012;33(3):18-21.

[42] Ghosh SK, Bandyopadhyay D, Ghosh A, Biswas SK, Mandal RK. Waardenburg syndrome: a report of three cases. Indian J Dermatol Venereol Leprol. 2010;76(5):550-2. doi:10.4103/0378-6323.69089.

[43] Melzer JM, Eliason M, Conley GS. Congenital stapes malformation: Rare conductive hearing loss in a patient with Waardenburg syndrome. Laryngoscope. 2016;126(4):992-5. doi:10.1002/lary.25443.

[44] Sayli BS, Akarsu AN, Altan S. Anophthalmos-syndactyly (Waardenburg) syndrome without oligodactyly of toes. Am J Med Genet. 1995;58(1):18-20. doi:10.1002/ajmg. 1320580105.

[45] Verheij JB, Sival DA, van der Hoeven JH, Vos YJ, Meiners LC, Brouwer OF, van Essen AJ. Waardenburg syndrome and PCWH associated with SOX10 mutations: a case report and review of the literature. Eur J Paediatr Neurol. 2006;10(1):11-7. doi:10.1016/j.ejpn. 2005.10.004.

[46] Sheffer R, Zlotogora J. Autosomal dominant inheritance of Klein-Waardenburg syndrome. Am J Med Genet. 1992;42(3):320-2. doi:10.1002/ajmg.1320420312.

[47] Bonnet JP, Till M, Edery P, Attie T, Lyonnet S. Waardenburg-Hirschsprung disease in two sisters: a possible clue to the genetics of this association? Eur J Pediatr Surg. 1996; 6(04):245-8. doi:10.1055/s-2008-1066521.

[48] Farndon PA, Bianchi A. Waardenburg's syndrome associated with total aganglionosis. Arch Dis Child. 1983;58(11):932-3. doi:10.1136/adc.58.11.932.

[49] Gnananayagam EJ, Solomon R, Chandran A, Anbarasi S, Sen S, Moses PD. Long segment Hirschsprung's disease in the Waardenburg-Shah syndrome. Pediatr Surg Int. 2003; 19(6):501-3. doi:10.1007/s00383-002-0944-7.

[50] Omenn GS, McKusick VA, Gorlin RJ. The association of Waardenburg syndrome and Hirschsprung megacolon. Am J Med Genet. 1979;3(3):217-23. doi:10.1002/ajmg. 1320030302.

[51] Pingault V, Girard M, Bondurand N, Dorkins H, Van Maldergem L, Mowat D, Shimotake T, Verma I, Baumann C, Goossens M. SOX10 mutations in chronic intestinal pseudo-obstruction suggest a complex physiopathological mechanism. Hum Genet. 2002; 111(2):198-206. doi:10.1007/s00439-002-0765-8.

[52] Sznajer Y, Coldéa C, Meire F, Delpierre I, Sekhara T, Touraine RL. A de novo SOX10 mutation causing severe type 4 Waardenburg syndrome without Hirschsprung disease. Am J Med Genet A. 2008;146(8):1038-41. doi:10.1002/ajmg.a.32247.

[53] Viñuela A, Morín M, Villamar M, Morera C, Lavilla MJ, Cavalle L, Moreno-Pelayo MA, Moreno F, del Castillo I. Genetic and phenotypic heterogeneity in two novel cases of Waardenburg syndrome type IV. Am J Med Genet A. 2009;149(10):2296-302. doi:10. 1002/ajmg.a.33026.

[54] Wang HH, Chen HS, Li HB, Zhang H, Mei LY, He CF, Wang XW, Men MC, Jiang L, Liao XB, et al. Identification and functional analysis of a novel mutation in the SOX10 gene associated with Waardenburg syndrome type IV. Gene. 2014;538(1):36-41. doi:10. 1016/j.gene.2014.01.026.

[55] Ahn BS, Oh SY. Clinical characteristics of CHARGE syndrome. Korean J Ophthalmol. 1998;12(2):130-4. doi:10.3341/kjo.1998.12.2.130.

[56] Angelman H. Syndrome of coloboma with multiple congenital abnormalities in infancy. Br Med J. 1961;1(5234):1212-4. doi:10.1136/bmj.1.5234.1212.

[57] Curatolo P, Libutti G, Brinchi V. Infantile spasms and the CHARGE association. Dev Med Child Neurol. 2008;25(3):367-9. doi:10.1111/j.1469-8749.1983.tb13773.x.

[58] Goldson E, Smith AC, Stewart JM. The CHARGE association. How well can they do? Am J Dis Child. 1986;140(9):918-21. doi:10.1001/archpedi.1986.02140230088040.

[59] Harvey AS, Leaper PM, Bankier A. CHARGE association: clinical manifestations and developmental outcome. Am J Med Genet. 1991;39(1):48-55. doi:10.1002/ajmg. 1320390112. 
[60] Ho CK, Kaufman RL, Podos SM. Ocular colobomata, cardiac defect, and other anomalies: a study of seven cases including two sibs. J Med Genet. 1975;12(3):289-93. doi:10. 1136/jmg.12.3.289.

[61] James PA, Aftimos S, Hofman P. CHARGE association and secondary hypoadrenalism. Am J Med Genet A. 2003;117(2):177-80. doi:10.1002/ajmg.a.10917.

[62] Marín JF, García B, Quintana A, Barrio R, Sordo MT, Lozano C. The CHARGE association and athyreosis. J Med Genet. 1991;28(3):207-8. doi:10.1136/jmg.28.3.207.

[63] Wood DJ, David TJ, Chrystie IL, Totterdell B. Chronic enteric virus infection in two Tcell immunodeficient children. J Med Virol. 1988;24(4):435-44. doi:10.1002/jmv. 1890240410.

[64] Berkiten G, Babalik M, Bal M, Onol S. Large vestibular aqueduct syndrome: report of 3 cases. Int J Anat Var. 2011;4:200-3.

[65] Clark JL, Roeser RJ. Large vestibular aqueduct syndrome: a case study. J Am Acad Audiol. 2005;16(10):822-8. doi:10.3766/jaaa.16.10.6.

[66] Griffith AJ, Arts A, Downs C, Innis JW, Shepard NT, Sheldon S, Gebarski SS. Familial large vestibular aqueduct syndrome. Laryngoscope. 1996;106(8):960-5. doi:10.1097/ 00005537-199608000-00009.

[67] Hazmi M, Aziz Asma AA. A. Familial pattern of large vestibular aqueduct syndrome in a Chinese family. Excli J. 2013;12:118-21.

[68] Mégarbané A, Chouery E, Rassi S, Delague V. A new autosomal recessive oto-facial syndrome with midline malformations. Am J Med Genet A. 2005;132(4):398-401. doi:10. 1002/ajmg.a.30479.

[69] Nowak KC, Messner AH. Isolated large vestibular aqueduct syndrome in a family. Ann Otol Rhinol Laryngol. 2000;109(1):40-4. doi:10.1177/000348940010900107.

[70] Pradhananga R, Natarajan K, Devarasetty A, Kameswaran M. Cochlear implantation in isolated large vestibular aqueduct syndrome: Report of three cases and literature review. Int Arch Otorhinolaryngol. 2015;19(4):359-63. doi:10.1055/s-0034-1395791.

[71] Varghese CM, Scampion P, Das VK, Gillespie J, Umapathy D. Enlarged vestibular aqueduct in two male siblings. Dev Med Child Neurol. 2007;44(10):706-11. doi:10.1111/j. 1469-8749.2002.tb00274.x.

[72] Ajij M, Shambhavi B, Patra A, Singh A, Kapoor S. Pendred Syndrome in a newborn with neck swelling: A case report. J Trop Pediatr. 2016;62(4):338-40. doi:10.1093/tropej/ fmw002.

[73] Banghova K, Cinek O, Taji EA, Zapletalova J, Vidura R, Lebl J. Thyroidectomy in a patient with multinodular dyshormonogenetic goitre-a case of Pendred syndrome confirmed by mutations in the PDS/SLC26A4 gene. J Pediatr Endocrinol Metab. 2008; 21(12):1179-84. doi:10.1515/jpem.2008.21.12.1179.

[74] Cremers WR, Bolder C, Admiraal RJ, Everet LA, Joosten FB, van Hauwe P, Green ED, Otten BJ. Progressive sensorineural hearing loss and a widened vestibular aqueduct in Pendred syndrome. Arch Otolaryngol Head Neck Surg. 1998;124(5):501-5. doi:10.1001/ archotol.124.5.501.

[75] Morgans ME, Trotter WR. Association of congenital deafness with goitre; the nature of the thyroid defect. Lancet. 1958;1(7021):607-9. doi:10.1016/s0140-6736(58)90866-3.

[76] Simões-Teixeira H, Matos TD, Marques MC, Dias Ó, Andrea M, Barreiros E, Barreiros L, Moreno F, Fialho G, Caria H, et al. Novel splice-site mutation c.1615-2A > G (IVS14$2 \mathrm{~A}>\mathrm{G})$ in the SLC26A4 gene causing Pendred syndrome in a consanguineous Portuguese family. Am J Med Genet A. 2011;155(4):924-7. doi:10.1002/ajmg.a.33740.

[77] Stinckens C, Huygen PL, Joosten FB, Van Camp G, Otten B, Cremers CW. Fluctuant, progressive hearing loss associated with Menière like vertigo in three patients with the Pendred syndrome. Int J Pediatr Otorhinolaryngol. 2001;61(3):207-15. doi:10.1016/ S0165-5876(01)00573-0.

[78] Derbent M, ??R??N UA, Varan B??l, Mercan ?k?, Yilmaz Z, Sahin FI, Tokel K??r. A new syndrome within the oculo-auriculo-vertebral spectrum: microtia, atresia of the external 
auditory canal, vertebral anomaly, and complex cardiac defects. Clin Dysmorphol. 2005; 14(1):27-30. doi:10.1097/00019605-200501000-00006.

[79] Dos Santos PA, de Oliveira SF, Freitas EL, Safatle HP, Rosenberg C, Ferrari I, Mazzeu JF. Non-overlapping 22q11.2 microdeletions in patients with oculo-auriculo-vertebral spectrum. Am J Med Genet A. 2014;164(2):551-3. doi:10.1002/ajmg.a.36231.

[80] Hacihamdioğlu B, Unay B, Hacihamdioğlu DO, Vurucu S, Gül D, Akin R. Goldenhar syndrome with duodenal atresia: a new finding. Clin Dysmorphol. 2008;17(2):141-2. doi: 10.1097/MCD.0b013e3282eff39f.

[81] Maat-Kievit JA, Baraitser M, Winter RM. Total situs inversus associated with the oculoauriculo-vertebral spectrum. Clin Dysmorphol. 1994;3(1):82-6.

[82] Mahore A, Dange N, Nama S, Goel A. Facio-auriculo-vertebro-cephalic spectrum of Goldenhar syndrome. Neurol India. 2010;58(1):141-4. doi:10.4103/0028-3886.60409.

[83] Merchant SN, Naimi TS, Khan A, Nadol JB, Jr, Holmes LB. Axial mesodermal dysplasia sequence: autopsy findings. Clin Dysmorphol. 2004;13(1):21-4. doi:10.1097/00019605200401000-00005.

[84] Tuna EB, Orino D, Ogawa K, Yildirim M, Seymen F, Gencay K, Maeda T. Craniofacial and dental characteristics of Goldenhar syndrome: a report of two cases. J Oral Sci. 2011; 53(1):121-4. doi:10.2334/josnusd.53.121.

[85] Yokochi K, Terasawa S, Kono C, Fujishima I. Dysphagia in children with oculo-auriculovertebral spectrum. Dysphagia. 1997;12(4):222-5. doi:10.1007/PL00009540.

[86] Dupuis C, Leuridan B, Peltier JM, Ducoulombier H, Nuyts JP, Mayolle P, Duchatelle A. [Jervell-Lange-Nielsen syndrome. Apropos of a case]. Arch Mal Coeur Vaiss. 1969;62(4): 563-76.

[87] Fraser GR, Froggatt P, James TN. Congenital deafness associated with electrocardiographic abnormalities, fainting attacks and sudden death. A recessive syndrome. Q J Med. 1964;33:361-85. doi:10.1093/oxfordjournals.qjmed.a067025.

[88] Lukoshevichume AI, Reǐngardene DI. Jervell and Lange- Nielsen syndrome. Kardiologiia. 1976;16(3):73-8.

[89] Sidel'nikov VM, Afanas'ev EN, Chashchevaia AA. Case of Jervell and Lange-Nielsen syndrome in a 5 1/2-year-old girl. Pediatriia. 1981;1:69-70.

[90] Al Rakaf M, Zakzouk SM, Al Shahwan SA. Jervell and Lange-Nielsen QT syndrome: a case report from Saudi Arabia. Int J Pediatr Otorhinolaryngol. 1997;39(2):163-8. doi:10. 1016/S0165-5876(96)01467-X.

[91] Bitoun P, Bandini D, Rigaudiere F. A hereditary syndrome with retinopathy and ataxia or deafness in two consanguineous brothers. Ophthalmic Paediatr Gene.t. 1991;12(3): 149-52. doi:10.3109/13816819109029397.

[92] Ghosh P, Sen DK. Congenital deafness and retinitis pigmentosa. Eye Ear Nose Throat Mon. 1970;49(6):292-6.

[93] Kapuscinski WJ, Uher M, Ogielska E. [Usher's syndrome. Description of 3 cases]. Bull Mem Soc Fr Ophtalmol. 1969;82:147-51.

[94] Trop I, Schloss MD, Polomeno R, Der Kaloustian V. Usher syndrome in four siblings from a consanguineous family of Pakistani origin. J Otolaryngol. 1995;24(2):102-4.

[95] Gilliam A, Williams ML. Fatal septicemia in an infant with keratitis, ichthyosis, and deafness (KID) syndrome. Pediatr Dermatol. 2002;19(3):232-6. doi:10.1046/j.1525-1470.2002. 00075.x.

[96] Jissendi-Tchofo P, Doherty D, McGillivray G, Hevner R, Shaw D, Ishak G, Leventer R, Barkovich AJ. Pontine tegmental cap dysplasia: MR imaging and diffusion tensor imaging features of impaired axonal navigation. AJNR Am J Neuroradiol. 2009;30(1):113-9. doi:10.3174/ajnr.A1305.

[97] Jovanovic M, Chinnathambi MZ, Markovic I, Abdrabon Eilewa ME, Sadeq SA, Moosa A. Pontine tegmental cap dysplasia: report of two new cases from Kuwait. Eur J Paediatr Neurol. 2015;19(1):93-7. doi:10.1016/j.ejpn.2014.08.005. 
[98] Leiva-Salinas C, Mukherjee S, Kesser BW, Deib G, Flors L, Raghavan P. Abnormalities of the cochlear nerves and internal auditory canals in pontine tegmental cap dysplasia. Otol Neurotol. 2012;33(9):73-4.

[99] Macferran KM, Buchmann RF, Ramakrishnaiah R, Griebel ML, Sanger WG, Saronwala A, Schaefer GB. Pontine tegmental cap dysplasia with a 2q13 microdeletion involving the NPHP1 gene: insights into malformations of the mid-hindbrain. Semin Pediatr Neurol. 2010;17(1):69-74. doi:10.1016/j.spen.2010.02.014.

[100] Barton ME, Court SD, Walker W. Causes of severe deafness in schoolchildren in Northumberland and Durham. Br Med J. 1962;1(5275):351-5. doi:10.1136/bmj.1.5275. 351.

[101] Hageman MJ, Oosterveld WJ. Vestibular findings in 25 patients with Waardenburg's syndrome. Arch Otolarygol. 1977;103(11):648-52. doi:10.1001/archotol.1977.007802800 48006.

[102] Wiener-Vacher SR, Amanou L, Denise P, Narcy P, Manach Y. Vestibular function in children with the CHARGE association. Arch Otolaryngol Head Neck Surg. 1999;125(3): 342-7. doi:10.1001/archotol.125.3.342.

[103] Abadie V, Wiener-Vacher S, Morisseau-Durand MP, Poree C, Amiel J, Amanou L, Peigne C, Lyonnet S, Manach Y. Vestibular anomalies in CHARGE syndrome: investigations on and consequences for postural development. Eur J Pediatr. 2000;159(8):569-74. doi:10.1007/s004319900409.

[104] Winbo A, Rydberg A. Vestibular dysfunction is a clinical feature of the Jervell and Lange-Nielsen Syndrome. Scand Cardiovasc J. 2015;49(1):7-13. doi:10.3109/14017431. 2014.988172.

[105] Möller CG, Kimberling WJ, Davenport SL, Priluck I, White V, Biscone-Halterman K, Odkvist LM, Brookhouser PE, Lund G, Grissom TJ. Usher syndrome: an otoneurologic study. Laryngoscope. 1989;99(1):73-9. doi:10.1288/00005537-198901000-00014.

[106] Desmadryl G. Postnatal development changes in the responses of mouse primary vestibular neurons to externally aplied galvanic currents. Dev Brain Res. 1991;64(1-2):137-43. doi:10.1016/0165-3806(91)90217-7. 